\section{Blue light induced apoptosis in rat retina}

\begin{abstract}
Purpose To explore cell death in blue light induced retinal damage.

Methods Sprague-Dawley rats reared under cyclic light were exposed continuously to diffuse blue light $(400-480 \mathrm{~nm})$ at $0.64 \mathrm{~W} / \mathrm{m}^{2}$ for 3 or $6 \mathrm{~h}$ after $22 \mathrm{~h}$ of dark adaptation. The rats were kept in darkness and killed immediately, 8, 16 and $24 \mathrm{~h}$ following light exposure. The retinal damage by the blue light was examined with a transmission electron microscope. The cell death was characterised by in situ terminal dUTP nick end labelling (TUNEL) and gel electrophoresis.
\end{abstract}

Results During the $24 \mathrm{~h}$ following light exposure, photoreceptor cell death was characterised by progressive condensation and margination of the chromatin, shrinkage or convolution and fragmentation of the nucleus, condensation of the cytoplasm, and formation of apoptotic bodies along with rapid removal of dying cells from damaged areas in the absence of inflammatory response. The TUNEL-positive nuclei were scattered individually in the outer nuclear layer just after light exposure. A wave of massive TUNEL labelling of photoreceptor nuclei peaked at 8-16 h and dropped at $24 \mathrm{~h}$ following light exposure. The distribution of TUNEL-positive nuclei was located predominantly at the upper temporal region of the retina, which was the most sensitive area to the damage caused by blue light.

Furthermore, the multiples of internucleosomal cleavage of 180-200 base pairs were demonstrated at corresponding time points.

Conclusion Photoreceptor cell apoptosis is seen early after the retina is damaged by blue light.

Key words Apoptosis, Blue light, Cell death, Light damage, Retina

It is well known that the retina can be damaged photochemically by visible light, ${ }^{1,2}$ especially the short wavelengths in the visible spectrum. ${ }^{3}$ Solar retinitis is mainly caused by a photochemical mechanism. ${ }^{3}$ Light damage might also be a predisposing factor in agerelated macular degeneration. ${ }^{4,5}$ Studies on
JIANGMEI WU, STEFAN SEREGARD, BERIT SPAONGBERG, MARGARETA OSKARSSON, ENPING CHEN animal models of retinitis pigmentosa suggest that minimising exposure to light may prolong useful vision of patients with certain subtypes of this disease. ${ }^{6,7}$ The photoreceptor cell is a consistent target in various models of photic injury. The wounded cell is commonly described as a pyknotic change with rapid disappearance from the damaged retina. The retinal pigment epithelium is also affected in certain circumstances. $^{8}$

Two modes of cell death have been differentiated in terms of morphology and mechanism, that is, apoptosis and necrosis. Necrosis is characterised by passive cell swelling and lysis. Early disruption of membrane integrity and cytoplasmic leakage promotes an inflammatory response. In contrast, apoptosis is a genetically regulated process of cell death. It is characterised by cell shrinkage, chromatin condensation or margination, nuclear fragmentation, cytoplasmic condensation and protuberance with relatively preserved organelles. The affected cell shrinks or breaks into membranebound apoptotic bodies that are recognised and phagocytosed by macrophages or neighbouring cells, or remain free in the absence of acute inflammation. Apoptosis usually involves scattered cells of the same tissue at different times. ${ }^{9,10}$

DNA of cells undergoing apoptosis is typically degraded into multiples of internucleosomal fragments of 180-200 base pairs that appear as a DNA ladder upon electrophoresis. ${ }^{11}$ The non-random cleavage of DNA, even if not a universal event, ${ }^{12}$ is considered a hallmark of apoptosis. In addition, DNA breaks can be visualised in situ by terminal dUTP nick end labelling (TUNEL). This method enables a quantitation of the process in a cell population. ${ }^{13}$

Apoptosis plays an important role in the regulation of cell numbers to control tissue development and maintain tissue homeostasis. ${ }^{9}$ Dysregulation of apoptosis has been reported in an increasing number of pathological conditions. ${ }^{14}$ In the retina, apoptotic cell death is seen in postnatal development, axotomy, ischaemia, degenerative diseases and experimental retinal detachment. ${ }^{15-23}$ Apoptosis has also been shown in human retina of
J. Wu

S. Seregard

B. Spångberg

M. Oskarsson

E. Chen

St Erik's Eye Hospital

Karolinska Institute

Stockholm, Sweden

Enping Chen, MD, PhD St Erik's Eye Hospital Karolinska Institute S-112 82 Stockholm Sweden

Tel: +46086723042 Fax: +46086723352 e-mail: enping.chen@ ophste.hs.sll.se

This study was supported by Karolinska Institutets Forskningsfonder, Edwin Jordans Stiftelse för Oftalmologisk Forskning, Einar och Anna Keys Resebidragsstiftelse, Carmen och Bertil Regners Stiftelse för Forskning inom Området Ögonsjukdomar, Stiftelsen Kronprinsessan Margaretas Arbetsnämnd för Synskadade

Received: 6 November 1998 Accepted in revised form: 14 April 1999 
retinoblastoma, pathological myopia, age-related macular degeneration and traumatic retinal detachment. ${ }^{24-26}$

A pathological study of retina damaged by green light (490-580 nm) suggests that apoptosis also underlines photoreceptor cell death, irrespective of the concurrent existence of necrotic changes in the same model. ${ }^{27}$ This morphological observation of apoptosis is further verified by biochemical evidence. ${ }^{28,29}$ A genetical study also supports a role for apoptosis in white light induced retinal damage. ${ }^{30}$ Moreover, retinal pigment epithelium damaged by white light is shown to die of apotosis. ${ }^{31}$ Evidence is given that the damaging effect of visible light on the retina is more powerful towards the shorter wavelength across the visible spectrum. ${ }^{32,33}$ The discrepancy in morphological change in the retina after similar exposures to green $(470-550 \mathrm{~nm})$ and blue light (400-440 nm) indicates that the damage mechanisms involved might be different from each other. ${ }^{33}$

Supplementation with ascorbate fails to protect the retina from blue light induced damage ${ }^{34}$ but does rescue the retina exposed to green light. ${ }^{35}$ The present study therefore aimed to explore cell death in blue light induced retinal damage.

\section{Materials and methods}

\section{Light exposure}

Female Sprague-Dawley rats were maintained in a 12:12 h light:dark cycle of 110 lux. They had free access to food and water. The rats, which weighed $170-180 \mathrm{~g}$, were dark-adapted for $22 \mathrm{~h}$ and continuously exposed to the blue light for 3 or $6 \mathrm{~h}$. Following light exposure, the rats were kept in darkness. The control rats went through all the experimental steps in darkness. Treatment of the animals was in conformity with the ARVO Statement on the Use of Animals in Ophthalmic and Vision Research.

The exposure device was composed of the light source and a rotating cage. ${ }^{36}$ Light of $400-480 \mathrm{~nm}$ was emitted from 16 tubular low-pressure mercury-vapour fluorescent lamps (Philips, The Netherlands) that were mounted vertically round the cage. Each lamp was incorporated into a spectrum tube (Sierra Polymer, Sparks, NV) to filter out the possible emission of UV radiation. The exposure cage was driven by an electric motor to rotate about a horizontal axis at a speed of $0.25 \mathrm{rpm}$ in order to keep the rats' eyes open during the exposure session. The mean irradiance inside the cage was $0.64 \mathrm{~W} / \mathrm{m}^{2}$, which was measured at the onset and the end of each exposure. The variation of light irradiance was $14 \%$ in the exposure cage when it was stationary.

\section{Electron microscopy}

The rats were killed with an overdose of pentobarbital. The eyes were immediately enucleated and fixed in $4 \%$ glutaraldehyde in $0.1 \mathrm{M}$ cacodylate buffer, $\mathrm{pH}$ 7.4, overnight. The upper temporal retina was dissected and post-fixed in $1 \%$ osmium tetroxide. Following serial dehydration, the tissue was stained with $2 \%$ uranyl acetate, and embedded in Agar 100. Sections of $1 \mu \mathrm{m}$ thickness were stained with $1 \%$ toluidine blue and examined with a light microscope. Sections of $0.1 \mu \mathrm{m}$ from damaged retina were prepared for electron microscopy.

\section{DNA fragmentation analysis by electrophoresis}

The retina was dissociated, frozen rapidly in liquid nitrogen and stored at $-80^{\circ} \mathrm{C}$. Two retinas from each rat were pooled, ground to a fine powder with a blender and incubated in Buffer ATL and proteinase $\mathrm{K}$ using QIAmp Tissue kit (Qiagen, Valencia, CA) at $55^{\circ} \mathrm{C}$ overnight. The lysate was extracted twice with an equal volume of phenol:chloroform:isoamylalcohol (25:24:1) and precipitated in $0.01 \mathrm{M} \mathrm{MgCl}_{2}$ and 2 volumes of ice-cold ethanol at $-20^{\circ} \mathrm{C}$ overnight. DNA was then washed in $70 \%$ ethanol, dried and resuspended. Five micrograms of DNA was loaded in a well of $1.7 \%$ agarose gel.

Electrophoresis was run at $4-5 \mathrm{~V} / \mathrm{cm}$. DNA was stained with ethidium bromide, visualised under UV light and photographed with Polaroid 667.

\section{TUNEL analysis}

The enucleated eyes were marked and fixed in $4 \%$ neutral buffered formaldehyde for 20-22 $\mathrm{h}$. The anterior segment was removed and the eye cup was oriented and embedded in paraffin by routine procedures. Sections of $4 \mu \mathrm{m}$ were cut in the sagittal plane, starting from a marked point that was located at the temporal side of the equator. Sections within the retinal lesion, lying 1.5 and $2.0 \mathrm{~mm}$ from the temporal mark, were selected for TUNEL staining.

TUNEL was performed using an ApopTag kit (Oncor, Gaithersburg, MD). Sections were deparaffinised and digested in $20 \mu \mathrm{g} / \mathrm{ml}$ proteinase $\mathrm{K}$. The sections were incubated stepwise in $2.0 \% \mathrm{H}_{2} \mathrm{O}_{2}$, equilibration buffer, and terminal deoxynucleotidyl transferase (TDT) with digoxigenin-dUTP. The reaction was terminated with Stop/Wash buffer. The sections were then incubated with anti-digoxigenin peroxidase. Staining was developed in 3-amino-9-ethylcarbazole (AEC). The sections were counter-stained with Mayer's haematoxylin. The negative control from each block was run by substituting an equal volume of distilled water for TDT enzyme. Similarly processed retinoblastoma specimens from patients were used as positive controls.

The number of TUNEL-positive nuclei in the outer nuclear layer (ONL) was counted on the whole sections by means of a manual counter. The counting was carried out after slide labels had been masked. For each rat, the quantification was. performed in either retina on two sections that were collected from an equivalent area as mentioned above. 


\section{Results}

\section{Electron microscopy}

The pathological changes in the retina were examined immediately and $24 \mathrm{~h}$ after 3 or $6 \mathrm{~h}$ of light exposure. Degenerating cells appeared among seemingly-normal cells in the ONL. The inner nuclear layer and ganglion cell layer were spared. The nuclei of dying cells were usually shrunken and round in shape (Fig. 1A).

Chromatin condensation to various degrees in combination with nuclear convolution (Fig. 1B) and nuclear fragmentation was shown in the affected nuclei. Cytoplasmic condensation was visible in some cells due to the scarcity of the cytoplasm in the ONL (Fig. 1B).

Occasionally, the apoptotic body formed was likely to be
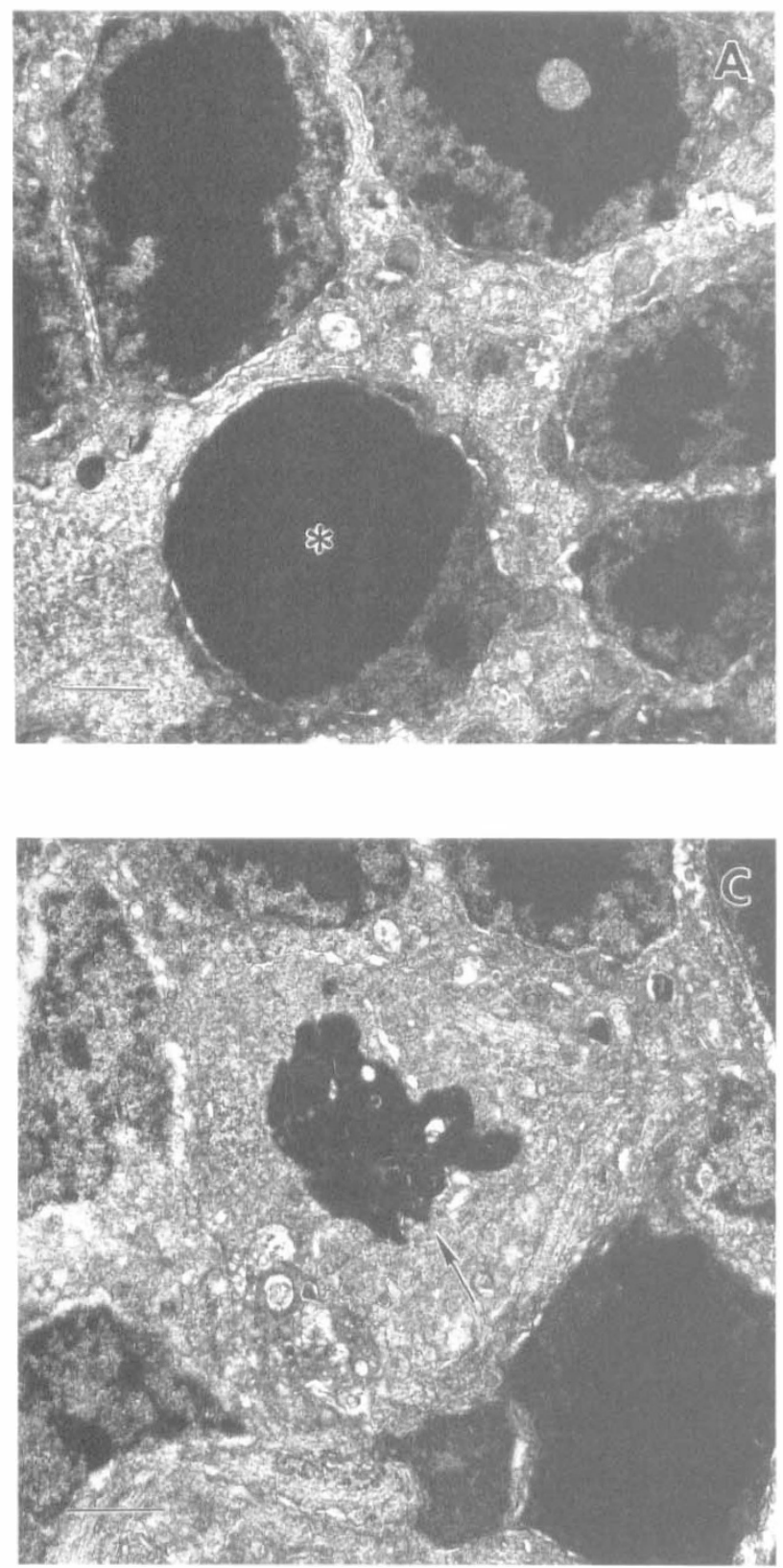

engulfed by and degraded within the Müller cell (Fig. 1C). Additionally, the blue light caused condensation of the inner segment with mild swelling of the mitochondria. The outer segments were vesiculated and disrupted. The retinal pigment epithelium was abnormal with condensed and marginated chromatin. Macrophages infiltrated the damaged area of the inner and outer segments (Fig. 1D). However, no inflammatory response was evident in sections subjected to inspection.

\section{DNA fragmentation analysis}

The retina specimens were acquired immediately, 16 and $24 \mathrm{~h}$ after cessation of the $6 \mathrm{~h}$ of light exposure. DNA was extracted and resolved by electrophoresis. The DNA

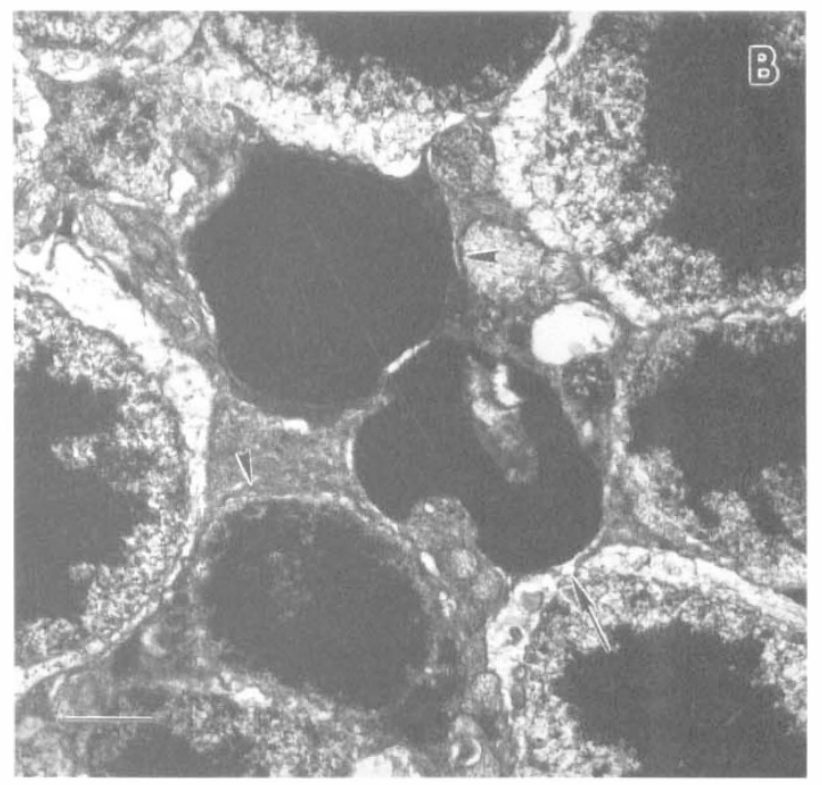

Fig. 1. Transmission electron micrographs. (A), (B) Photoreceptor shrinkage (asterisk), cytoplasm and chromatin condensation (arrowheads) and nuclear convolution (arrow). (C) The engulfment and degradation of an apoptotic body in the Müller cell (arrow). (D) The infiltration of the macrophage in the damaged area of the inner and outer segments. Scale bar represents $1 \mu \mathrm{m}$. 


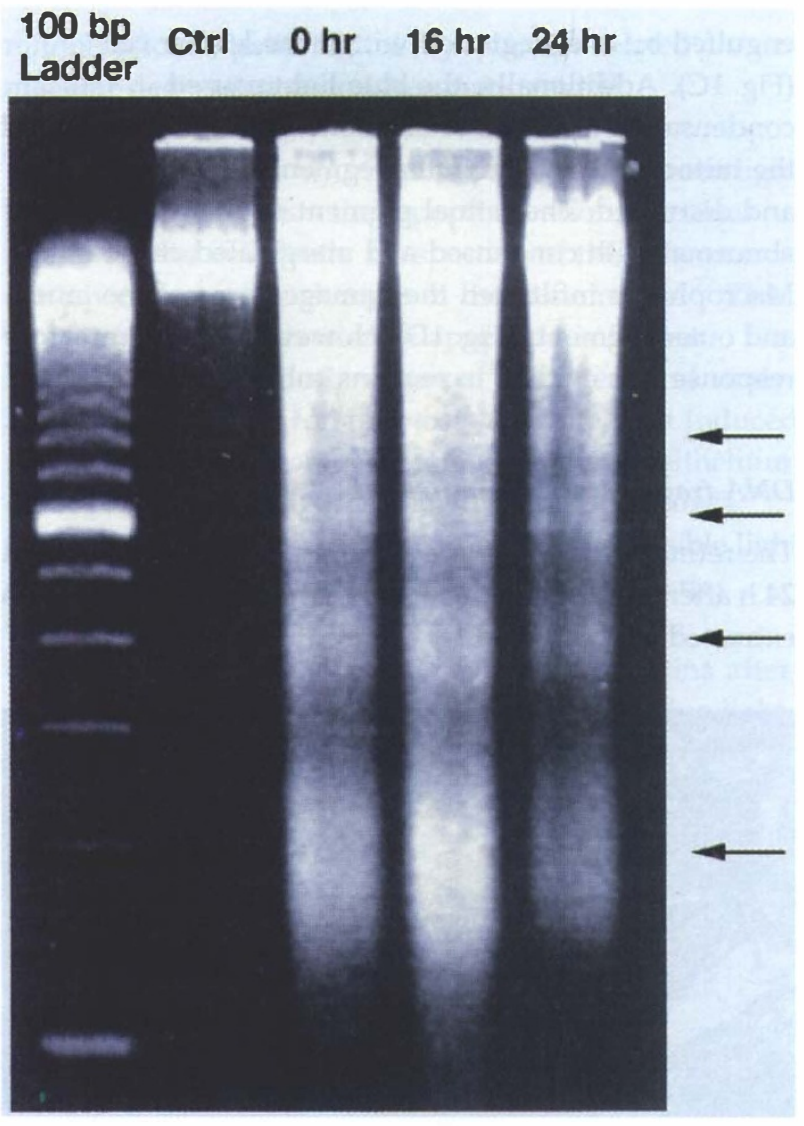

Fig. 2. DNA fragmentation analysis by gel electrophoresis. The retinal samples were obtained immediately, 16 and $24 \mathrm{~h}$ following $6 \mathrm{~h}$ of exposure to blue light. The ladder pattern of non-random

internucleosomal cleavage was displayed at all time points. No DNA ladder was present in the unexposed control. ladder that coincided with the multiples of 180-200 base pairs was present at all time points (Fig. 2), indicating the presence of internucleosomally cleaved DNA fragments. The intensity of the DNA ladder was highest at $16 \mathrm{~h}$, and lowest at $24 \mathrm{~h}$. No DNA ladder was present in the unexposed retina.

\section{TUNEL analysis}

Two groups of the rats, 10 in each, were light-exposed for 3 or $6 \mathrm{~h}$. Two rats of each group were killed immediately, 8,16 and $24 \mathrm{~h}$ following light exposure. Two other rats served as an unexposed control. A number of TUNELpositive nuclei were scattered individually just after light exposure, mostly near the inner aspect of the ONL

(Fig. 3B, F). The staining was dense along the nuclear periphery, resulting in a nuclear-rim pattern. Long-term exposure produced a higher number of stained nuclei. Increased labelling was observed and reached a peak between 8 and $16 \mathrm{~h}$ after light exposure (Fig. 3C, D, G, H). The labelled nuclei were sporadic or in small clusters during this period. The labelling was greatly reduced at $24 \mathrm{~h}$ following light exposure (Fig. 3E, I). The TUNELpositive nuclei were predominantly situated in the upper region of the temporal retina in which a considerable loss of photoreceptor nuclei was exhibited during the postexposure period of $24 \mathrm{~h}^{34}$ The temporal pattern of TUNEL staining in the ONL is also illustrated quantitatively in Fig. 4. The TUNEL labelling was detected only in the ONL. No TUNEL-positive nuclei were seen in unexposed retina (Fig. 3A) and negative control.

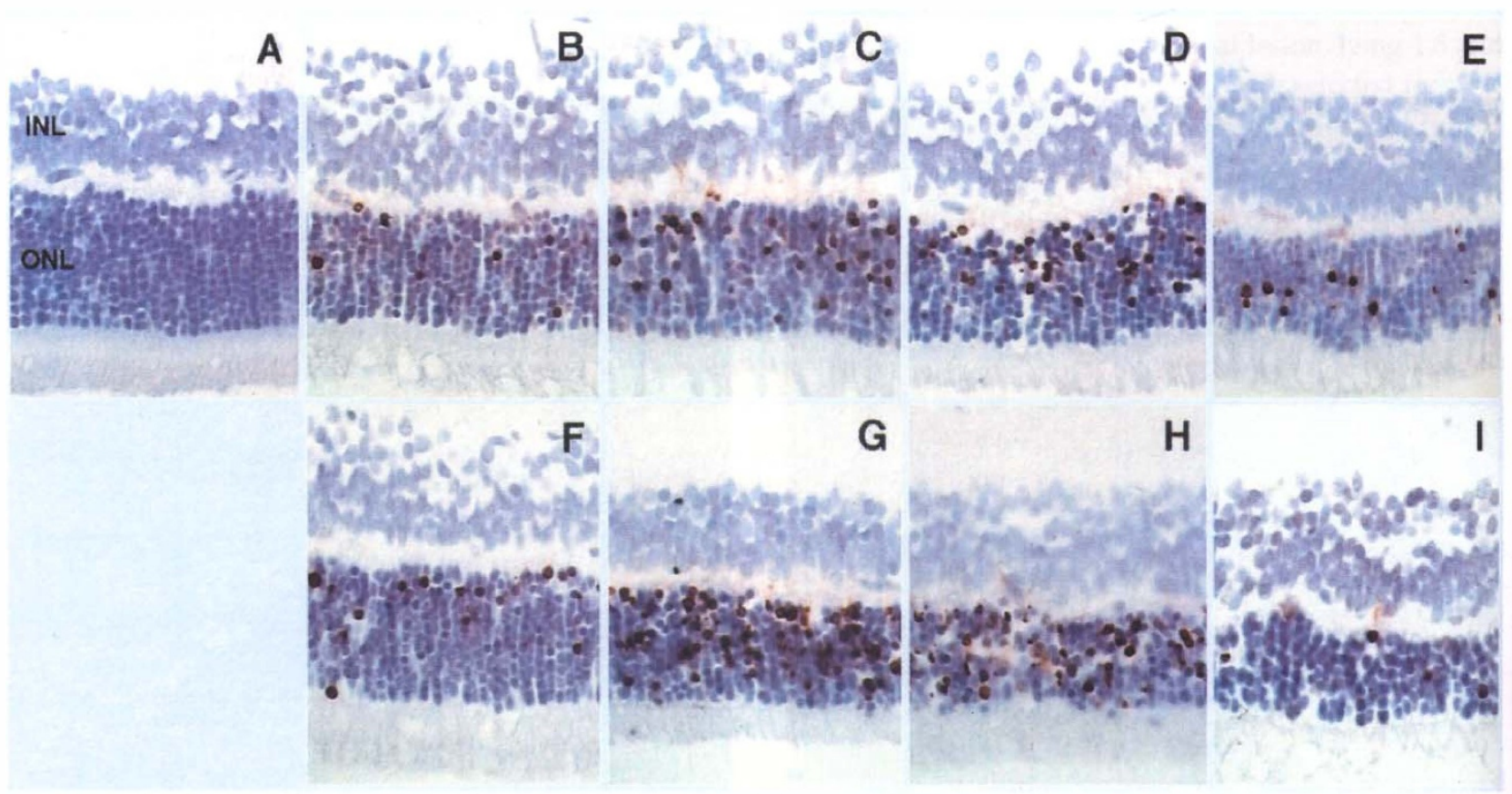

Fig. 3. TUNEL analysis of retinal sections after continuous exposure to blue light for $3 h(B-E)$ or $6 h$ (F-I). The specimens were collected just after light exposure $(B, F)$, and $8 h(C, G), 16 h(D, H)$ and $24 h(E, I)$ after withdrawal of the light. The red TUNEL labelling of photoreceptor nuclei appeared in all sections except for an unexposed control (A). INL, inner nuclear layer; ONL, outer nuclear layer. 


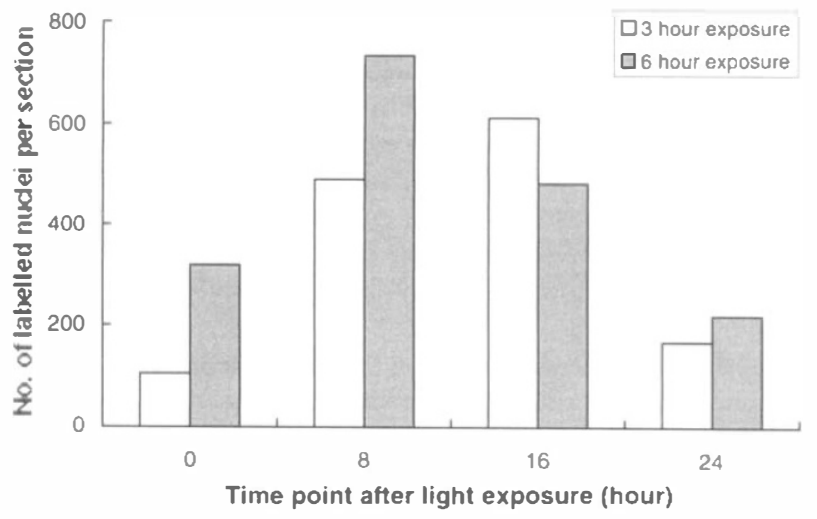

Fig. 4. Quantitative illustration of TUNEL labelling. The mean of the number of labelled nuclei was derived from four retinal sections of two rats at each time point. The peak labelling was shown at 8-16 h after blue light exposure.

\section{Discussion}

The present study explored retinal cell death induced in vivo by diffuse exposure to blue light at lower intensity. Albino rats were used in this experiment. The blue light triggered early photoreceptor cell death in a sporadic pattern. Cell death was characterised by chromatin condensation, nucleus shrinkage or convolution and fragmentation, and cytoplasm condensation. Apoptotic bodies were seen in the absence of inflammatory response. These morphological alterations are more consistent with the stereotyped features of apoptosis rather than necrosis. ${ }^{9,10}$ Nonetheless, the apoptotic changes in the photoreceptor cell exhibited certain deviations from those of other cell types. ${ }^{9,10}$ The chromatin of the photoreceptor cell was condensed to a compact, electron-dense body instead of undergoing aggregation and margination and being 'sharply delineated, finely granular masses of uniform texture' ${ }^{10}$ However, the appearance of chromatin margination was infrequently visible in the apoptotic body undergoing degradation in the present study. Different cell types appear to have some discrepancies in the morphology of otherwise similar death patterns. ${ }^{37,38}$ The pathological changes in the ONL caused by the blue light were comparable to the previous findings in which cell death is believed to follow an apoptotic pathway. ${ }^{27,28,37}$

It has been mentioned that the quantitative evaluation of TUNEL staining is always underestimated, owing to the fact that apoptotic cells are removed rapidly from the tissue, ${ }^{9}$ and yet it still illustrates a dynamic process of cell death induced by exogenous signals. Immediately following light exposure, $6 \mathrm{~h}$ of exposure caused more labelled photoreceptor nuclei than did $3 \mathrm{~h}$ of exposure, indicating a positive correlation of dose-response. However, the degenerative process did not halt after withdrawal of the light. The number of TUNEL-positive nuclei increased, peaking at 8-16 h after light exposure. The DNA laddering of multiples of 180-200 base pairs seen during this period supported an underlying mechanism of apoptosis. Although it is currently unclear whether the apoptotic cell death occurring in light-on and light-off periods is signalled by the same molecule(s), the delayed wave of cell death is more likely triggered by secondary molecular events arising from a cascade of photochemical reactions, and the damage mechanism lasted for some time and diminished at $24 \mathrm{~h}$ following the blue light exposure.

The analysis of the temporal course of photoreceptor cell death further corroborated that there was no sustained accumulation of TUNEL-positive cells in the retinas following the dramatic loss of photoreceptor cells. Apoptotic bodies can be degraded even though they remain free. ${ }^{10}$ Phagocytosis of apoptotic bodies by Müller cells or other neighbouring cells, as well as infiltration by macrophages, is also likely to be involved in the rapid removal of dying cells from damaged retina. The phagocytic activity of the Müller cell has been reported in programmed cell death during retinal development. ${ }^{39,40}$ A previous study showed that the exposure to diffuse blue light preferentially damaged the upper temporal retina, as manifest by the loss of the photoreceptor cells. ${ }^{34}$ In the current study, the TUNEL labelling pattern in the ONL paralleled the severity of retinal damage, though the reason for the regional sensitivity remains obscure. In conclusion, apoptotic cell death of photoreceptor cells is seen at an early stage following exposure to blue light.

The temporal profile of the visual cell loss in this study was not in full agreement with previous findings, ${ }^{28}$ where the number of TUNEL-positive cells increased with recovery time up to $24 \mathrm{~h}$ after continuous light exposure. This could be explained by the fact that a number of factors affect retinal damage by light, such as light history, nutritional state, age, genetic background and experimental paradigm. ${ }^{8}$ Blue light has been shown to damage mitochondria, inhibit respiration and inactivate cytochrome oxidase in in vitro studies. ${ }^{41-44}$ The mitochondrion is the most vulnerable organelle in photic injury, particularly in blue light induced retinal damage. ${ }^{45}$ Blue light exposure irreversibly inhibits cytochrome oxidase, causing inner segment and photoreceptor damage. ${ }^{46}$ A previous study also revealed an increased calcium concentration in the inner segment after blue light exposure. ${ }^{47}$ Interestingly, recent work proposes a role for the mitochondrion in apoptosis. ${ }^{48}$ Dysregulation of mitochondrial functions has been related to the elevation of cytosolic $\mathrm{Ca}^{2+}$ concentration, ${ }^{49}$ an important messenger in the regulation of apoptosis in various cell lines. ${ }^{50}$ However, the correlation of mitochondrion dysfunction in blue light induced apoptosis needs to be further investigated.

The present study links apoptosis with blue light induced retinal damage. It is in agreement with the idea that apoptosis is a final common pathway of retinal cell loss resulting from divergent primary defects. Moreover, it provides a key to disclosing the basis of photoreceptor cell death in photic injury by blue light and opens the possibility of intervention in this process. 


\section{References}

1. Noell WK, Walker VS, Kang BS, Berman S. Retinal damage by light in rats. Invest Ophthalmol 1966;5:450-73.

2. Ham WT Jr, Mueller HA, Sliney DH. Retinal sensitivity to damage from short wavelength light. Nature 1976;260:153-5.

3. Ham WT Jr, Mueller HA, Ruffolo JJ Jr, Clarke AM. Sensitivity of the retina to radiation damage as a function of wavelength. Photochem Photobiol 1979;29:735-43.

4. Young RW. Pathophysiology of age-related macular degeneration. Surv Ophthalmol 1987;31:291-306.

5. Taylor HR, Munoz B, West S, Bressler NM, Bressler SB, Rosenthal FS. Visible light and risk of age-related macular degeneration. Trans Am Ophthalmol Soc 1990;88:163-73.

6. Wang M, Lam TT, Tso MO, Naash MI. Expression of a mutant opsin gene increases the susceptibility of the retina to light damage. Vis Neurosci 1997;14:55-62.

7. Naash ML, Peachey NS, Li ZY, Gryczan CC, Goto Y, Blanks J, Milam AH, Ripps H. Light-induced acceleration of photoreceptor degeneration in transgenic mice expressing mutant rhodopsin. Invest Ophthalmol Vis Sci 1996;37:775-82.

8. Noell WK. Possible mechanisms of photoreceptor damage by light in mammalian eyes. Vision Res 1980;20:1163-71.

9. Kerr JF, Wyllie AH, Currie AR. Apoptosis: a basic biological phenomenon with wide-ranging implications in tissue kinetics. Br J Cancer 1972;26:239-57.

10. Kerr JF, Gobe GC, Winterford CM, Harmon BV. Anatomical methods in cell death. Methods Cell Biol 1995;46:1-27.

11. Wyllie AH. Glucocorticoid-induced thymocyte apoptosis is associated with endogenous endonuclease activation. Nature 1980;284:555-6.

12. Cohen GM, Sun XM, Snowden RT, Dinsdale D, Skilleter DN Key morphological features of apoptosis may occur in the absence of internucleosomal DNA fragmentation. Biochem J 1992;286:331-4.

13. Gavrieli Y, Sherman Y, Ben-Sasson SA. Identification of programmed cell death in situ via specific labelling of nuclear DNA fragmentation. J Cell Biol 1992;119:493-501.

14. Webb SJ, Harrison DJ, Wyllie AH. Apoptosis: an overview of the process and its relevance in disease. Adv Pharmacol 1997;41:1-34.

15. Young RW. Cell death during differentiation of the retina in the mouse. J Comp Neurol 1984;229:362-73.

16. Garcia-Valenzuela E, Gorcyzca W, Darzynkiewicz Z, Sharma SC. Apoptosis in adult retinal ganglion cells after axotomy. J Neurobiol 1994;25:431-8.

17. Rosenbaum DM, Rosenbaum PS, Gupta A, Michaelson MD, Hall DH, Kessler JA. Retinal ischemia leads to apoptosis which is ameliorated by aurintricarboxylic acid. Vision Res 1997;37:3445-51.

18. Chang GQ, Hao Y, Wong F. Apoptosis: final common pathway of photoreceptor death in $r d, r d s$, and rhodopsin mutant mice. Neuron 1993;11:595-605.

19. Portera-Cailliau C, Sung $\mathrm{CH}$, Nathans J, Adler R. Apoptotic photoreceptor cell death in mouse models of retinitis pigmentosa. Proc Natl Acad Sci USA 1994;91:974-8.

20. Lolley RN, Rong H, Craft CM. Linkage of photoreceptor degeneration by apoptosis with inherited defect in phototransduction. Invest Ophthalmol Vis Sci 1994;35:358-62.

21. Tso MO, Zhang C, Abler AS, Chang CJ, Wong F, Chang GQ, Lam TT. Apoptosis leads to photoreceptor degeneration in inherited retinal dystrophy of RCS rats. Invest Ophthalmol Vis Sci 1994;35:2693-9.

22. Smith SB, Bora N, McCool D, Kutty G, Wong P, Kutty RK, Wiggert B. Photoreceptor cells in the vitiligo mouse die by apoptosis. TRPM-2/clusterin expression is increased in the neural retina and in the retinal pigment epithelium. Invest Ophthalmol Vis Sci 1995;36:2193-201.

23. Cook B, Lewis GP, Fisher SK, Adler R. Apoptotic photoreceptor degeneration in experimental retinal detachment. Invest Ophthalmol Vis Sci 1995;36:990-6.
24. Buchi ER, Bernauer W, Daicker B. Cell death and disposal in retinoblastoma: an electron microscopic study. Graefes Arch Clin Exp Ophthalmol 1994;232:635-45.

25. Xu GZ, Li WW, Tso MO. Apoptosis in human retinal degenerations. Trans Am Ophthalmol Soc 1996;94:411-30.

26. Chang CJ, Lai WW, Edward DP, Tso MO. Apoptotic photoreceptor cell death after traumatic retinal detachment in humans [see comments]. Arch Ophthalmol 1995;113:880-6.

27. Shahinfar S, Edward DP, Tso MO. A pathologic study of photoreceptor cell death in retinal photic injury. Curr Eye Res 1991;10:47-59.

28. Li S, Chang CJ, Abler AS, Fu J, Tso MO, Lam TT. A comparison of continuous versus intermittent light exposure on apoptosis. Curr Eye Res 1996;15:914-22.

29. Abler AS, Chang CJ, Ful J, Tso MO, Lam TT. Photic injury triggers apoptosis of photoreceptor cells. Res Commun Mol Pathol Pharmacol 1996;92:177-89.

30. Hafezi F, Steinbach JP, Marti A, Munz K, Wang ZQ, Wagner EF, Aguzzi A, Reme CE. The absence of c-fos prevents lightinduced apoptotic cell death of photoreceptors in retinal degeneration in vivo [see comments]. Nature Med 1997;3:346-9.

31. Hafezi F, Marti A, Munz K, Reme CE. Light-induced apoptosis: differential timing in the retina and pigment epithelium. Exp Eye Res 1997;64:963-70.

32. Ham WT Jr, Ruffolo JJ Jr, Mueller HA, Guerry D III. The nature of retinal radiation damage: dependence on wavelength, power level and exposure time. Vision Res 1980;20:1105-11.

33. Gorgels TG, van Norren D. Ultraviolet and green light cause different types of damage in rat retina. Invest Ophthalmol Vis Sci 1995;36:851-63.

34. Wu J, Chen E, Söderberg PG. Failure of ascorbate to protect broadband blue light induced retinal damage on rat. Graefes Arch Clin Exp Ophthalmol 1999; in press.

35. Organisciak DT, Wang HM, Li ZY, Tso MO. The protective effect of ascorbate in retinal light damage of rats. Invest Ophthalmol Vis Sci 1985;26:1580-8.

36. Chen $\mathrm{E}, \mathrm{Wu}$ J. A novel device that keeps rats' eyes open during light exposure. Lasers Light Ophthalmol 1999; in press.

37. Buchi ER. Cell death in rat retina after pressure-induced ischaemia-reperfusion insult: electron microscopic study. II. Outer nuclear layer. Jpn J Ophthalmol 1992;36:62-8.

38. Buchi ER. Cell death in the rat retina after a pressureinduced ischaemia-reperfusion insult: an electron microscopic study. I. Ganglion cell layer and inner nuclear layer. Exp Eye Res 1992;55:605-13.

39. Penfold PL, Provis JM. Cell death in the development of the human retina: phagocytosis of pyknotic and apoptotic bodies by retinal cells. Graefes Arch Clin Exp Ophthalmol 1986;224:549-53.

40. Egensperger R, Maslim J, Bisti S, Hollander H, Stone J. Fate of DNA from retinal cells dying during development: uptake by microglia and macroglia (Muller cells). Brain Res Dev Brain Res 1996;97:1-8.

41. Pautler EL, Morita M, Beezley D. Hemoprotein(s) mediate blue light damage in the retinal pigment epithelium. Photochem Photobiol 1990;51:599-605.

42. Pautler EL, Morita M, Beezley D. Reversible and irreversible blue light damage to the isolated, mammalian pigment epithelium. Prog Clin Biol Res 1989;314:555-67.

43. Ninnemann H, Butler WL, Epel BL. Inhibition of respiration and destruction of cytochrome A3 by light in mitochondria and cytochrome oxidase from beef heart. Biochim Biophys Acta 1970;205:507-12.

44. Ninnemann H; Butler WL, Epel BL. Inhibition of respiration in yeast by light. Biochim Biophys Acta 1970;205:499-506. 
45. Lawwill T. Three major pathologic processes caused by light in the primate retina: a search for mechanisms. Trans Am Ophthalmol Soc 1982;80:517-79.

46. Chen E. Inhibition of enzymes by short-wave optical radiation and its effect on the retina. Acta Ophthalmol Suppl 1993;71:1-50

47. Chen E, Pallon J, Forslind B. Distribution of calcium and sulphur in the blue-light-exposed rat retina. Graefes Arch Clin Exp Ophthalmol 1995;233:163-7.
48. Zamzami N, Susin SA, Marchetti P, Hirsch T, GomezMonterrey I, Castedo M, Kroem G. Mitochondrial control of nuclear apoptosis [see comments]. J Exp Med 1996;183:1533-44.

49. Richter $\mathrm{C}$. Reactive oxygen and nitrogen species regulate mitochondrial $\mathrm{Ca}^{2+}$ homeostasis and respiration. Biosci Rep 1997;17:53-66.

50. McConkey DJ, Orrenius S. Signal transduction pathways in apoptosis. Stem Cells 1996;14:619-31. 